\title{
Association between ABO Blood/ Rhesus Grouping and Hepatitis C virus in Egyptian patients
}

\author{
${ }^{1}$ Hussam K.M. Sahow, ${ }^{1}$ Samir H. Abdel Aziz, ${ }^{1}$ Sabah A. Abo Maaty, ${ }^{2}$ Sohair Abdel \\ Rahman and ${ }^{3}$ El Dougdoug K. A.
}

${ }^{1}$ Dept. of Microbiology, Fac. of Sci., Benha Univ., Egypt.

${ }^{2}$ Dept. of Clinical Pathology, Fac. of Medicine, Benha Univ., Egypt.

${ }^{3}$ Dept. of Microbiology, Fac. of Agric., Ain Shams Univ., Cairo Egypt.

Received: 05 August 2019/ Accepted 20 Sept. 2019/Publication date: 15 Oct. 2019

\begin{abstract}
The relationship between hepatitis $\mathrm{C}$ virus and the host $\mathrm{ABO} / \mathrm{Rh}$ blood groups appropriately designed study in Egypt. This current study aimed to investigate possible association between ABO blood /Rh groups with $\mathrm{HCV}$ infection. In this study, 20 healthy individuals (controls), 90 patients showed like Hepatitis-C symptoms were recruited from June 2018 to March 2019 provided clinical labs in Egypt. The HCV patients groups were matched for their subjects, region, age and sex. In the $\mathrm{HC}$ group, there were $75 \mathrm{Rh}+$ positive $(83.3 \%)$ and $15 \mathrm{Rh}$ - negative $(16.6 \%)$ patients. The corresponding figures were (A) 16/23 (69.7\%), (B) 17/25 (68\%), (O) 8/20 (40\%) and (AB) 17/22 $(54.5 \%)$ for the $\mathrm{HCV}$ patients out of $\mathrm{AB}$ blood groups. Comparing between the control and $\mathrm{HC}$ groups showed no significant difference in terms of the frequency of $\mathrm{ABO}$ blood groups $(p=0.70)$. The HCV patients appeared Severe symptoms thus as, Fever, Joint pain, Weight loss, Liver cell failure and mild symptoms thus as, (Nausea, Vomiting and Abdominal pain. HCV Positive clinical blood 73 out of 90 with rate $81.1 \%$ by ELISA. Statistical significant differences were recorded between $\mathrm{HCV}$ and blood groups, A, B, O and $\mathrm{AB}$ regarding sex. In addition there was highly statistical significant decrease in female than male cases regarding medical history. While nonsignificant differences between $\mathrm{ABO}$ blood groups of $\mathrm{HCV}$ patient regarding $\mathrm{CB}$ Cresults, Biochemical Liver tests and Kidney function, (creatinine and Urea). RT-qPCR of blood viral load showed that the higher percentage of HCV infection was among $\mathrm{f}$ blood group B $(54.90 \%)$ and the lower percentage was among those of blood group O $(9.90 \%)$ with significant difference $(p<0.05)$ .This association is significant between certain ABO blood groups and HCV.
\end{abstract}

Keywords: HCV, ABO blood groups, ELISA, RT-PCR, rt- RT-PCR

\section{Introduction}

Hepatitis infection by virus $\mathrm{C}(\mathrm{HCV})$ is among the most serious and very prevalent diseases. The viral infectious disease is among the major health problems, especially in developing countries (Rifatuz-Zaman, 2006; Hejazi et al., 2007; Bidgoli et al., 2007; Hemeida et al., 2011; Sohail et al., 2011; Kilic et al., 2012; Barakat et al., 2012; Abo Elmagd et al., 2011).

According to official reports, over 200 million individuals suffer from chronic HCV infection all over the world. Its prevalence varies between $0.1 \%$ in western countries to over $18 \%$ in developing regions. It is believed that the most efficient transmission of $\mathrm{HC}$ virus is via blood transfusion (Barth et al., 2006; Zeisel et al., 2009).

The association between various infectious diseases and blood groups has been discussed enthusiastically during recent decades. It has been proposed that this connection is possibly due to interaction between microorganisms and red blood cell membrane, which can be justified by antigenic similarity, affinity toward common receptors or deregulation of antibody response (Mandell, 2009).However, to the best of our knowledge, there has not been yet a well-designed case-control study in this regard in the literature. The present study aimed to investigate a possible association between $\mathrm{ABO} /$ rhesus $(\mathrm{Rh})$ blood groups and hepatitis $\mathrm{C}$ infections in Egyptian patients.

Corresponding Author: Hussam K.M. Sahow, Dept. of Microbiology, Fac. of Sci., Benha Univ., Egypt. 


\section{Materials and Methods}

This study was attended to Fac. of Sci. Banha Univ., provide clinical labs and Hospital Alexandaria, El Qalubyia and El Fayom governorates, Egypt. It was done on 90 patients and 20apparently healthy subjects served as control group from June 2018 to March 2019. All patients gave informed consent for participation in this study.

\section{Collecting clinical specimens.}

The patients were selected randomly from out patient clinic of hepatology in 3 shared hospital .Ten $\mathrm{ml}$ of venous blood samples were obtained by peripheral vein puncture under aseptic precaution from all patients. Two $\mathrm{ml}$ of blood on sodium citrate to perform pro thrombin time. $2 \mathrm{ml}$ on EDTA tube for CBC. The blood specimens were refrigerated and arrived to the laboratory through one hour. The rest of blood was drawn in plain tube then put in water path at $37 \mathrm{C}^{\circ}$ for 30 minutes then centrifuged at low speed for 10 minutes then the resultant serum was divided in aliquots and Stored at $-20 \mathrm{C}^{\circ}$ for analysis .

\section{Determination of $\mathrm{ABO}$ blood groups:}

$\mathrm{ABO}$ blood and rhesus (Rh) grouping was performed based on conventional methods. according to Marion and Christine (2004). Accordingly, subjects were categorized as ABO blood group $\mathrm{A}, \mathrm{B}, \mathrm{O}$, or $\mathrm{AB}$ and $\mathrm{Rh}$-positive ( $\mathrm{Rh}+$ ) or Rh-negative (Rh-). One drop of each anti $\mathrm{A}$ and anti $B$ was put in sterilized labeled serological tube. One drop of tested RBCs 5\% suspension was added to each labeled tube. The tubes were mixed and centrifuged at low speed for seconds. The RBCs pellet was re suspended in saline buffer and examined using slide agglutination assay.

Detecting antibodies in serum: $3^{\text {th }}$ generation enzyme linked Immunosorbent assay (ELISA) according to Chan, (2009). Calculate the cut-off value and evaluate the results. Interpretation of the result of the plate readers. Calculation of the cut-off: Cut-off value (C.O.) $=* \mathrm{NC}+0.12$.

$* \mathrm{NC}=$ the mean absorbance value for the three negative controls.

Calculation of the concentration:

Positive sample $=($ sample $/$ cut off $)>1$.

Negative sample $=($ sample $/$ cut off $)<1$.

Complete blood count (CBC) by (XP-300), Sysmex Automated peripheral smear examination.

Alanine amino transferase (ALT). The reversible transamination of the amino group between Lalanine and 2-oxoglutarate to form L-glutamate and pyruvate. The pyruvate formed reacts with NADH in the presence of lactate dehydrogenase (LDH) to form NAD. The oxidation rate of NADH to NAD was measured as a decrease in absorbance which is proportional to the ALT activity at $340 \mathrm{~nm}$ (Henry, 1991).

Aspartate amino transferase (AST) .The reversible transamination of amino group between Laspartate and $\alpha$-ketoglutarate to form oxaloacetate and glutamate. The oxaloacetate formed reacts with NADH in the presence of malate dehydrogenase (MDH) to form NAD. The oxidation rate of NADH to NAD was measured as a decrease in absorbance which is proportional to the AST activity in Serum at $340 \mathrm{~nm}$ (Henry, 1991).

Serum bilirubin (Total \& Direct) : Total Bilirubin is coupled with diazotized sulphanilic acid in the presence of caffeine to give a colored diazo dye measured at wavelength $578 \mathrm{~nm}$ by Colorimetric Diazo method by (A15)(Biosystem). (Thomas, 1998). Direct Bilirubin is coupled with diazotized sulphanilic acid in the absence of caffeine to give a red-colored azobilirubin measured at wave length $546 \mathrm{~nm}$ by Colorimetric Diazo method by (A15) (Biosystem) (Thomas, 1998).

Serum Albumin gm/dl. Determination of serum albumin is based on its binding to bromocresol green (BCG) at PH 4.2 to form a blue-green colored complex which determined by monitoring the increase in absorbance at $578 \mathrm{~nm}$ by Colorimetric Diazo method by (A15) (Biosystem) (Tietz, 1987). 
Prothrombin time (PT) /sec. Thromboplastin activates the coagulation factors of extrinsic system in plasma in the presence of calcium ions. The clotting time depends on the concentration of factors I, II, $\mathrm{V}$, VII and X. A prolonged clotting time indicates deficiency of one or several of these factors (Colman et al., 1994) The result may be reported as a ratio $\mathrm{R}: \mathrm{I} N \mathrm{R}$.

Creatinine: At an alkaline solution, creatinine combines with acid to form an orange-red colored complex. The absorbency increase is directly proportional to the concentration of creatinine by Modified Jaffe method by A15Biosystem (Burtis and Ashwood, 1999).

Urea: Urea in the sample originates, by means a coloured complex that can be measured by spectrophotometry. The increase of absorbancence per minute at wavelength $405 \mathrm{~nm}$ is proportional to the enzyme activity (Tietz et al., 1983).

Alpha fetoprotein (AFP): The following steps were done as recommended by Sophia Ave., Van Nuys, CA 91406 US, France. A monoclonal anti-AFP antibody conjugated to horse radish peroxidase (HRPO) is in the antibody-enzyme conjugate solution.

\section{Real time Polymerase Chain Reaction (rt -RT-PCR)}

Extraction of HCV RNA. The HCV RNA was released and protected from RNases in serum by incubatied with a protease and chaotropiclysis in binding buffer. The mixture was incubated with the magnetic glass beads. The RNA was bound to the surface of the magnetic glass beads and unbound substances salts and other cellular impurities were removed by washing the magnetic glass beads. The adsorbed RNA was eluted at elevated temperature with an aqueous solution (Colucci et al., 2011).

Reverse transcription of the target RNA to generate complementary DNA (cDNA): Target region for HCV subtyping was a 339-nucleotides, the specific primers were forward primer $\left(5^{\prime}\right.$ ctgtgaggaactactgtcttcacgcag3') and reverse primer (5'ctagtcgcgcgcacaccca3'). The enzymes and amplification conditions according to Quer et al. (2015). cDNA was carried according to manufacturer 's instructions. Template RNA $5 \mu 1$ was mixed with $2 \mu 1$ of complement primer set in $! / 2 \mathrm{ml} \mathrm{PCR}$ Ependorf tube. The mixture was incubated at $70{ }^{\circ} \mathrm{C}$ for $5 \mathrm{~min}$, and was placed on ice for $1 \mathrm{~min}$ and added $5 \mu \mathrm{l}$ RTase then filled up the reaction volume with nuclease free water to $20 \mu \mathrm{l}$. The tube was transferred to AccuPower ${ }^{\circledR}$ RT-PCR PreMix tube and Incubated at $42^{\circ} \mathrm{C} / 60 \mathrm{~min}$ for cDNA synthesis and then Incubated at $94^{\circ} \mathrm{C}$ for $5 \mathrm{~min}$ for RTase inactivation.

Amplification of cDNA. A real-time PCR reaction mixture could be $50 \mu \mathrm{l}$, the following mixture in each optical tube was prepared. $25 \mu \mathrm{l}$ SYBR Green Mix (2x), $5 \mu \mathrm{l}$ cDNA, $2 \mu 1$ primer pair mix (5 $\mathrm{pmol} / \mu \mathrm{l}$ each primer), and $22.5 \mu \mathrm{l} \mathrm{H}_{2} \mathrm{O}$. A copy of the setup file was saved and deleted all PCR cycles. $50^{\circ} \mathrm{C} 2 \mathrm{~min}, 1$ cycle, $95^{\circ} \mathrm{C} 10 \mathrm{~min}, 1$ cycle $, 95^{\circ} \mathrm{C} 15 \mathrm{~s} \rightarrow 60{ }^{\circ} \mathrm{C} 30 \mathrm{~s}->72{ }^{\circ} \mathrm{C} 30 \mathrm{~s}, 40$ cycles, and $72^{\circ} \mathrm{C} 10 \mathrm{~min}, 1$ cycle.

\section{Generation of standard curves}

Dilution endpoint standard curves were determined and compared for HCV by performing realtime RT-PCR with10-fold dilutions of positive control for HCV. The threshold $(\mathrm{Ct})$ value obtained from the assay of each dilution was used to plot a standard curve by assigning a value of 1 RT-PCR unit (RT-PCRU) to the highest dilution showing a positive Ct and10, 100, and 1,000 RT-PCRU sequentially to the lower dilutions. Data were used to plot standard curves (fig.1).

Statistical analysis: Data were shown as Mean \pm Standard Deviation or number (\%). The SPSS software for Windows (ver.16) was used. Independent samples t test (for age) and the Chi-square test (for sex and the status of $\mathrm{ABO}$ blood groups and $\mathrm{Rh}$ ) were employed for analyzing. All comparisons were performed in two pairs: Control group vs. HB group and control group vs. HC group. $p=0.05$ was considered statistically significant. 


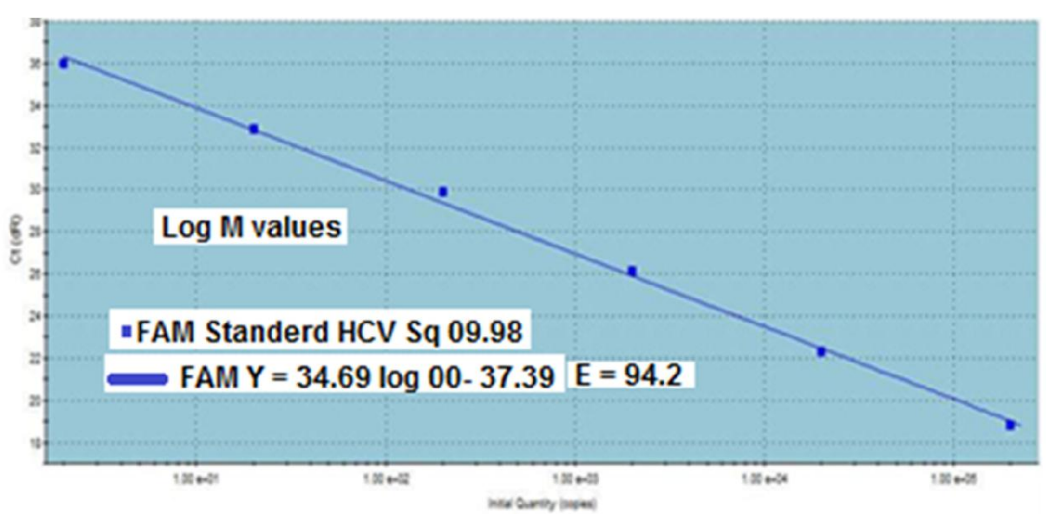

Fig. 1: Standerd Curve obtained by Excicycler Real-Time PCR .

\section{Results}

\section{Seropositivity rates of $\mathrm{HCV}$ infections according to blood groups :}

The highest percentage of HCV infection among blood group patients was blood group O (8/20) 40 $\%$, followed by B (17/25) $68 \%$, A (16/23) $69.7 \%$, and AB (17/22) $54.5 \%$ for seroprevalence with significant differences $(\mathrm{p}<0.015)($ Fig, 2$)$.

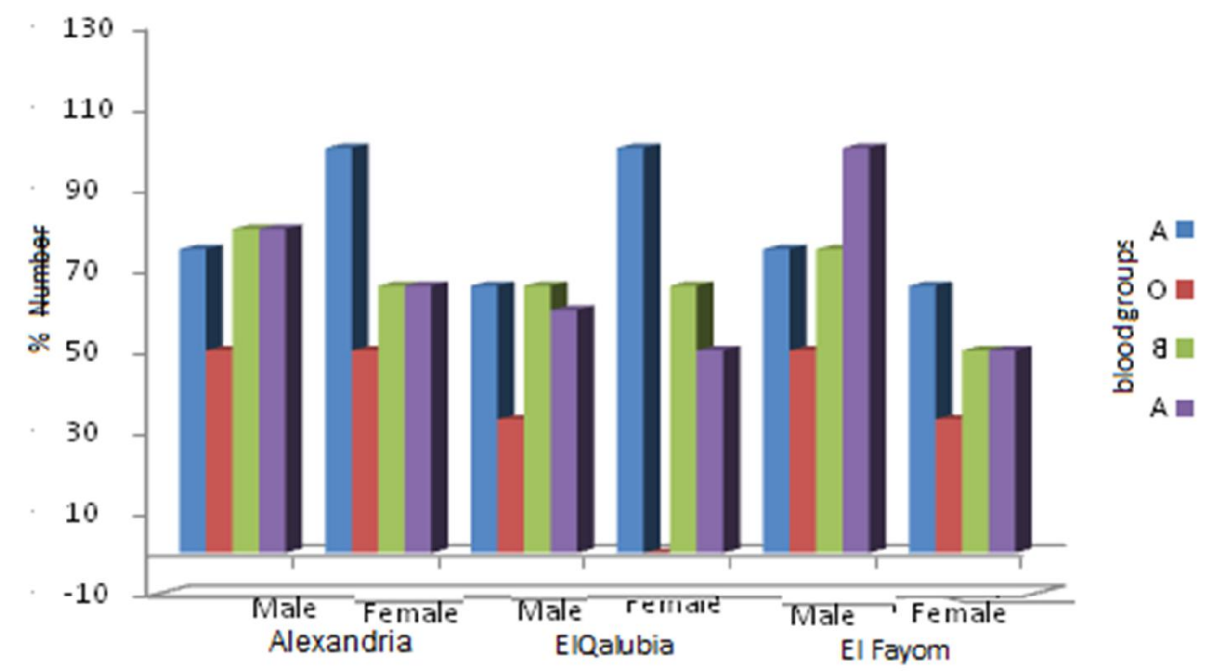

Fig. 2: Histogram showing Percentages of seropositivity of HCV infections according to blood groups.

\section{HCV diagnosis:}

HCV disease was treated in 90 patients, (54) males and (36)females with different age under studied distanced like symptoms of $\mathrm{HCV}$ disease collected from different hospitals belong to Alessandria, El Qalubyia and El Fayom (table,1) .The cases under studied seropositivity belong to blood groups, A(23), B (26) ,O (18) and AB (23 cases) (table,1). The HCV disease was diagnosed based on:

Clinical Symptoms of hepatitis C: The HCV patients appeared Severe symptoms thus as, (Fever $(\mathrm{Fe})$, Joint pain $(\mathrm{J})$ ), (Weight loss (W), Liver cell failure (L)) and Mild symptoms thus as, (Nausea $(\mathrm{N})$, Vomiting (V) and Abdominal pain (A). 
Enzyme linked immunosorbent assay (ELISA): was used to detect HCV antibody in 90 clinical samples under studied. Positive clinical blood 73 out of 90 with rate $81.1 \%$ which defined the optical density (OD) of test clinical blood exceed that of Cut off value ; $\geq 0.24$ (table 1 ).

Table 1: HCV detection in cases belong blood groups, $\mathrm{A}, \mathrm{B}, \mathrm{O}$ and $\mathrm{AB}$ in different hospitals

\begin{tabular}{|c|c|c|c|c|c|c|}
\hline Location & Six & Age group & Blood group & NO & ILFST & ELISA \\
\hline \multirow{8}{*}{$\begin{array}{c}\text { Alexandria } \\
\quad 30\end{array}$} & \multirow{3}{*}{ Males } & \multirow{3}{*}{$>30$ years } & $\mathrm{A}$ & 5 & $3 / 5$ & $* 4 / 5$ \\
\hline & & & B & 5 & $3 / 5$ & $* 3 / 5$ \\
\hline & & & $\mathrm{O}$ & 4 & $2 / 4$ & $* 2 / 4$ \\
\hline & \multirow{5}{*}{ Females } & \multirow{5}{*}{$>45$ years } & $\mathrm{AB}$ & 4 & $3 / 4$ & $* 4 / 4$ \\
\hline & & & $\mathrm{AB}$ & 3 & $2 / 3$ & $* 3 / 3$ \\
\hline & & & A & 3 & $1 / 3$ & $* 2 / 3$ \\
\hline & & & $\mathrm{B}$ & 4 & $3 / 4$ & $* 4 / 4$ \\
\hline & & & $\mathrm{O}$ & 2 & $0 / 2$ & $* 1 / 2$ \\
\hline \multirow{8}{*}{$\begin{array}{c}\text { El Qalubyia } \\
\mathbf{3 0}\end{array}$} & \multirow{3}{*}{ Males } & \multirow{3}{*}{$>35$ years } & $\mathrm{O}$ & 3 & $1 / 3$ & $* 2 / 3$ \\
\hline & & & $\mathrm{AB}$ & 6 & $4 / 6$ & $* 5 / 6$ \\
\hline & & & $\mathrm{A}$ & 5 & $3 / 5$ & $* 4 / 5$ \\
\hline & \multirow{5}{*}{ Females } & \multirow{5}{*}{$>65$ years } & B & 6 & $4 / 6$ & $* 5 / 6$ \\
\hline & & & B & 3 & $2 / 3$ & $* 3 / 3$ \\
\hline & & & $\mathrm{O}$ & 2 & $1 / 2$ & $* 2 / 2$ \\
\hline & & & $\mathrm{AB}$ & 3 & $2 / 3$ & $* 3 / 3$ \\
\hline & & & A & 2 & $1 / 2$ & $* 1 / 2$ \\
\hline \multirow{8}{*}{$\begin{array}{c}\text { El Fayom } \\
\mathbf{3 0}\end{array}$} & \multirow{5}{*}{$\begin{array}{c}\text { Males } \\
16\end{array}$} & \multirow{4}{*}{$\begin{array}{c}>40 \text { years } \\
16\end{array}$} & $\mathrm{O}$ & 4 & $2 / 4$ & $* 2 / 4$ \\
\hline & & & $\mathrm{AB}$ & 4 & $3 / 4$ & $* 4 / 4$ \\
\hline & & & $\mathrm{A}$ & 4 & $3 / 4$ & $* 4 / 4$ \\
\hline & & & B & 4 & $3 / 4$ & $* 4 / 4$ \\
\hline & & \multirow{4}{*}{$\begin{array}{c}>35 \text { years } \\
14\end{array}$} & B & 4 & $2 / 4$ & $* 3 / 4$ \\
\hline & \multirow{3}{*}{$\begin{array}{c}\text { Females } \\
14\end{array}$} & & $\mathrm{O}$ & 3 & $3 / 3$ & $* 2 / 3$ \\
\hline & & & $\mathrm{AB}$ & 3 & $2 / 3$ & $* 3 / 3$ \\
\hline & & & A & 4 & $3 / 4$ & $* 3 / 4$ \\
\hline 90 & 90 & 90 & 90 & 90 & $47 / 90$ & $* 73 / 90$ \\
\hline
\end{tabular}

*ELISA positive reaction was defined (OD) exceed Cut off value ; $\geq 0.24$

There was statistical significant difference between patients and blood groups, $\mathrm{A}, \mathrm{B}, \mathrm{O}$ and $\mathrm{AB}$ regarding age. The age $>35$ was highly statistical significant increased compared with $>30 \mathrm{c},>40,>$ 45 and $>65$ age regarding medical history. On the other hand it was statistical significant lowed in blood groups $\mathrm{O}$ than blood groups, A,B and AB (Fig. 3).

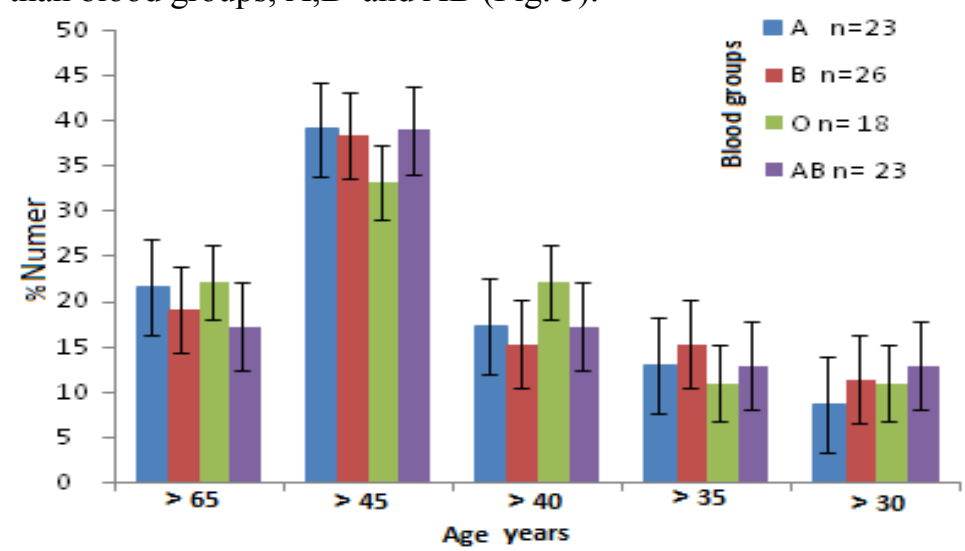

Fig. 3: Histogram showing Risk factor of chronic HCV among blood groups regarding age or sex group.

There was statistical significant difference between patients and blood groups, A, B, O and AB regarding sex where as statistical significant decreased in Blood group $\mathrm{O}$. In addition there was highly statistical significant decrease in female than male (Fig.4). 


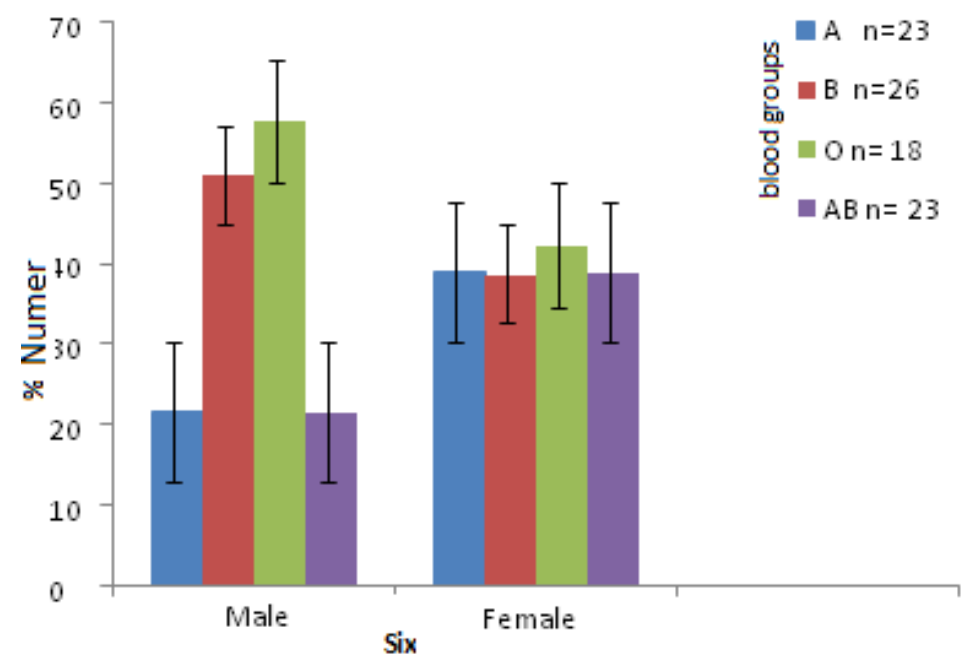

Fig. 4: Histogram showing Risk factor of chronic HCV among blood groups regarding sex group.

There was statistical no significant difference between patients and blood groups, A, B, O and $\mathrm{AB}$ regarding $\mathrm{HCV}$ distribution in governorates where as statistical significant decreased in Blood group $\mathrm{O}$ regarding medical history. (Fig. 5)

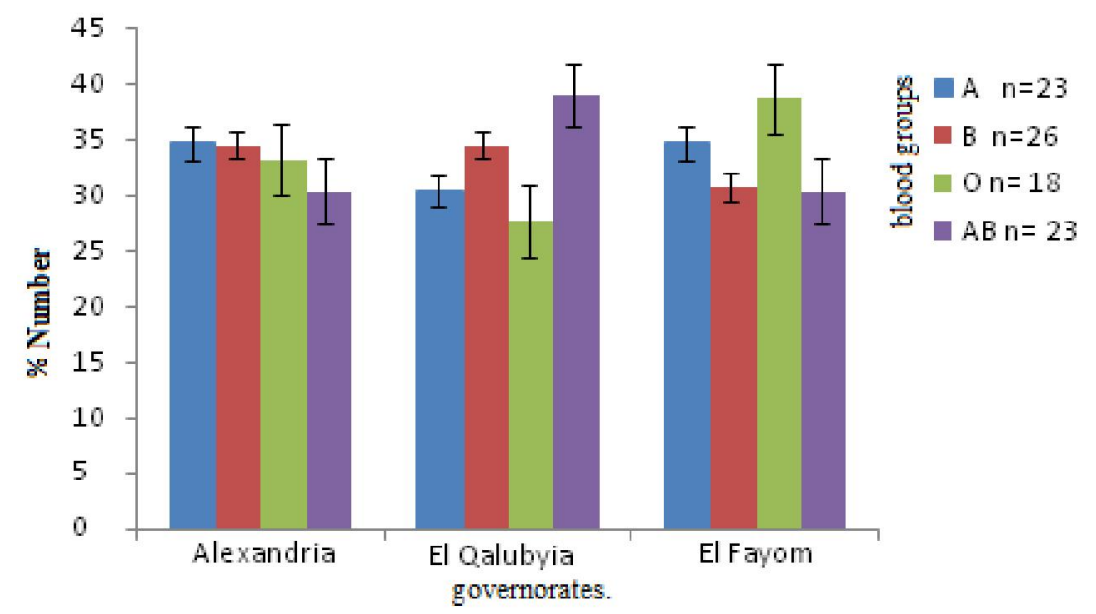

Fig. 5: Histogram showing Risk factor of chronic $\mathrm{HCV}$ among blood groups regarding governorates.

CBC results: It was found that no significant differences between $\mathrm{ABO}$ blood groups of $\mathrm{HCV}$ patient regarding hemoglobin (HB) and PLT platelets (PLT) (Fig. 6 ) .

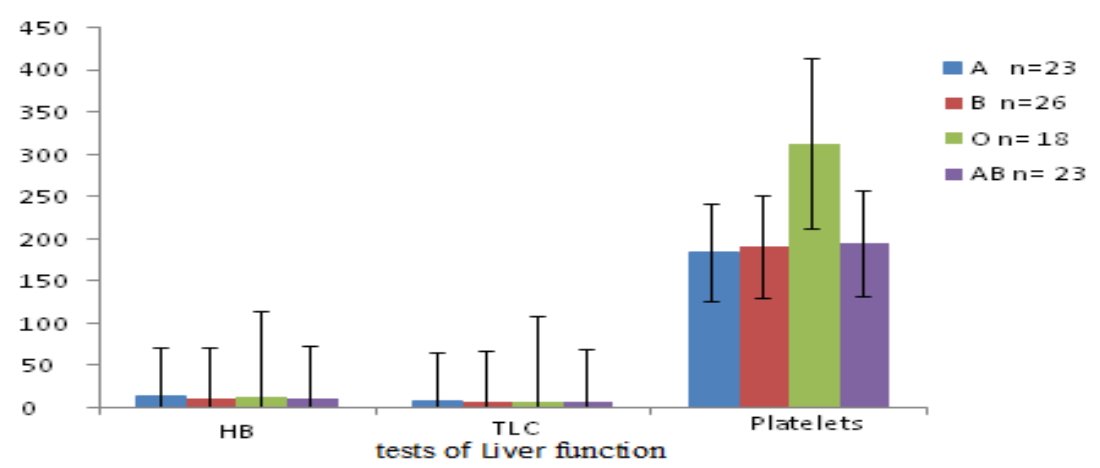

Fig. 5: $\mathrm{CBC}$ of Liver for $\mathrm{ABO}$ blood groups of $\mathrm{HCV}$ patient. 
Biochemical Liver tests: There was statistical no significant differences between ABO blood groups of HCV patients with liver function tests (Fig.7). Also statistical non significant differences in Bilirubin values in HCV patients cases (Fig. 7).

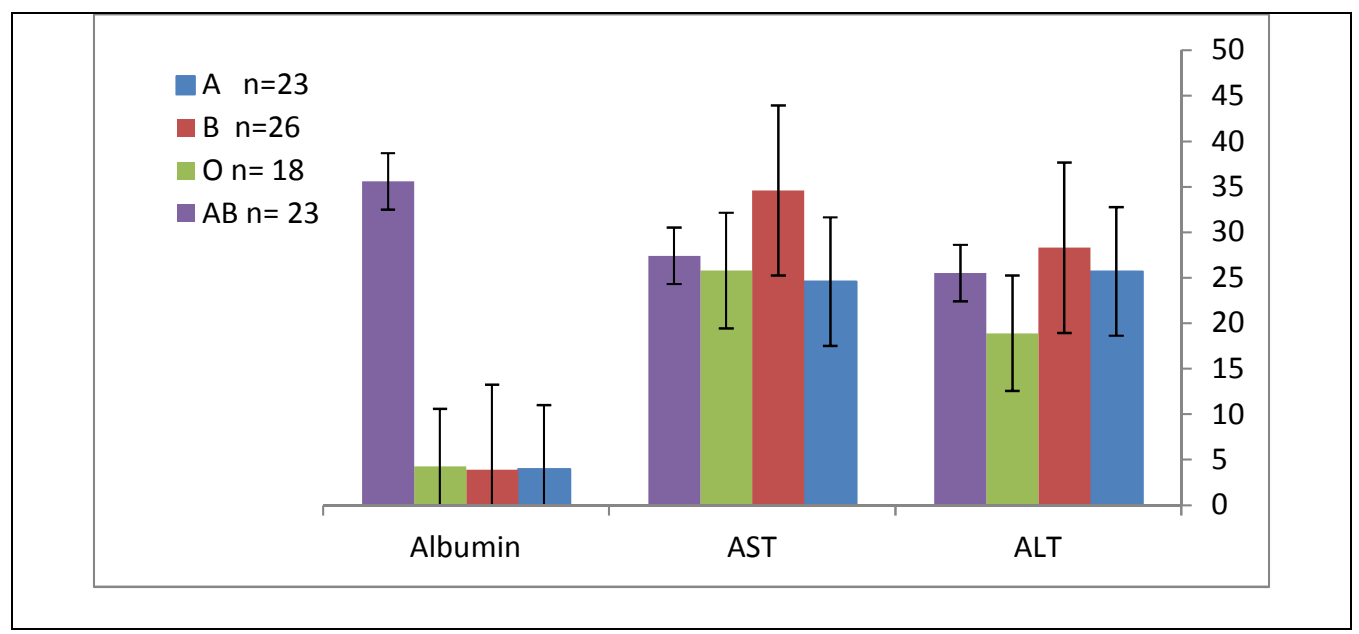

Fig. 7: Biochemical tests of Liver function for ABO blood groups HCV patient

Kidney function: It was found statistical no significant differences between ABO blood groups of $\mathrm{HCV}$ patients regarding (creatinine and Urea) .There is statistical significant increase in urea in treated cases than control cases. (Fig. 8)

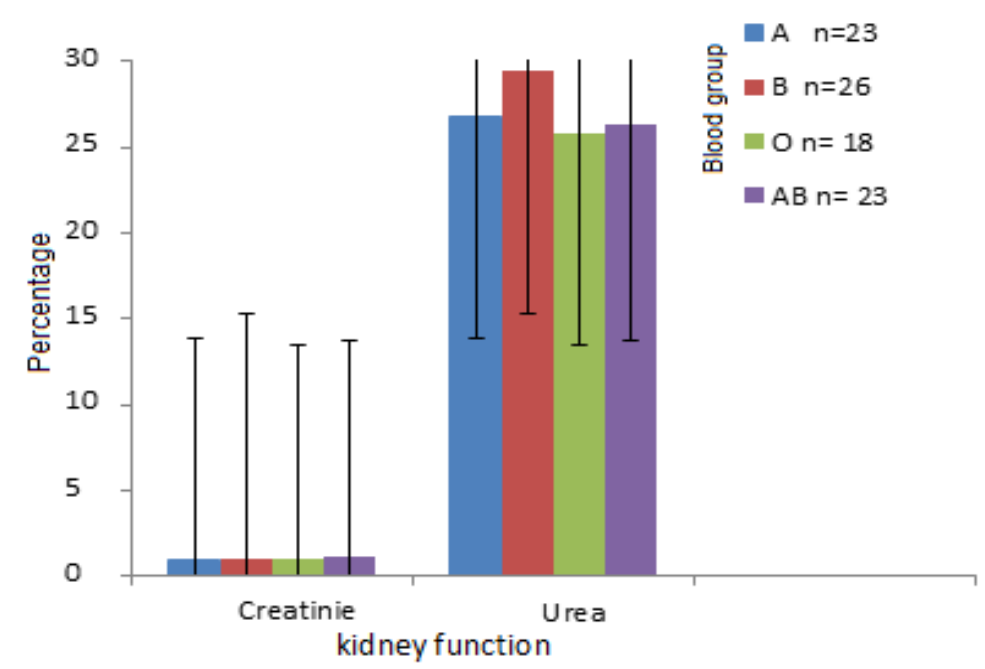

Fig. 8: Biochemical tests of kidney function for $\mathrm{ABO}$ blood groups

Relationship between quantitative HCV RNA and quantitative HCV antibodies in HCV patients among blood groups regarding sex and age: It was found that no relation between blood groups regarding sex and age to HCV antibodies concentration and number of HCV RNA. It was found that quantitative HCV HCV RNA depended on concentration HCV antibodies in HCV patients. -rt (RT) PCR was done depending on ELISA concentration. It was found HCV antibodies concentration was high $=>$ high HCV RNA. Also, noticed variation as a category of HCV patients on follow up showing rapid recovery and marvelous decline in PCR concentration. The category showing slow decline in PCR concentration on follow up. So, regarding to ELISA results $=>$ PCR was done and depending on its results. 
Table 2: Serum quantitative HCV PCR depended on quantitative HCV antibodies ELISA in HCV patients among blood groups regarding sex and age.

\begin{tabular}{|c|c|c|c|c|}
\hline ABO blood groups & Sex & Age years & ELISA titre & rt-RT-PCR \\
\hline \multirow{8}{*}{ Blood group $\mathbf{A}$} & \multirow{4}{*}{ Female } & \multirow{2}{*}{$>30$} & 97.14 & $1.18^{*} 10^{\wedge} 3$ \\
\hline & & & 91.17 & $3.12 * 10^{\wedge} 5$ \\
\hline & & \multirow[b]{2}{*}{$>60$} & 75.25 & $1.4^{*} 10^{\wedge} 4$ \\
\hline & & & 85.16 & $2.55^{*} 10^{\wedge} 3$ \\
\hline & \multirow{4}{*}{ Male } & \multirow[b]{2}{*}{$>30$} & 125.18 & $6.11^{*} 10^{\wedge} 3$ \\
\hline & & & 135.76 & $6.11^{*} 10^{\wedge} 3$ \\
\hline & & \multirow{2}{*}{$>60$} & 140.56 & $2.11^{*} 10^{\wedge} 4$ \\
\hline & & & 235.87 & $2.71 * 10^{\wedge} 6$ \\
\hline \multirow{8}{*}{ Blood group $B$} & \multirow{4}{*}{ Female } & \multirow{2}{*}{$>30$} & 91.56 & $3.23^{*} 10^{\wedge} 6$ \\
\hline & & & 98.26 & 2. $25^{*} 10^{\wedge} 6$ \\
\hline & & $>60$ & 85.25 & $2.27^{*} 10^{\wedge} 6$ \\
\hline & & years & 110.18 & $1.15^{*} 10^{\wedge} 6$ \\
\hline & \multirow{4}{*}{ Male } & \multirow{2}{*}{$>30$ years } & 192.67 & $9.1 * 10^{\wedge} 4$ \\
\hline & & & 161.87 & $2.61 * 10^{\wedge} 2$ \\
\hline & & \multirow{2}{*}{$>60$ years } & 155.50 & $2.11^{*} 10^{\wedge} 2$ \\
\hline & & & 211.56 & $2.8 * 10^{\wedge} 3$ \\
\hline \multirow{8}{*}{ Blood group $\mathbf{O}$} & \multirow{4}{*}{ Female } & \multirow{2}{*}{$>30$ years } & 97.15 & $2.20^{*} 10^{\wedge} 6$ \\
\hline & & & 101.32 & $1.11^{*} 10^{\wedge} 6$ \\
\hline & & \multirow{2}{*}{$>60$ years } & 92.75 & $1.66^{*} 10^{\wedge} 6$ \\
\hline & & & 96.51 & $1.20 * 10^{\wedge} 6$ \\
\hline & \multirow{4}{*}{ Male } & \multirow{2}{*}{$>30$ years } & 180.75 & $1.17^{*} 10^{\wedge} 6$ \\
\hline & & & 187.76 & $1.27 * 10^{\wedge} 6$ \\
\hline & & \multirow{2}{*}{$>60$ years } & 182.45 & $2.33 * 10^{\wedge} 6$ \\
\hline & & & 171.43 & $1.22 * 10^{\wedge} 6$ \\
\hline \multirow{8}{*}{ Blood group AB } & \multirow{4}{*}{ Female } & \multirow{2}{*}{$>30$ years } & 157.16 & $2.26^{*} 10^{\wedge} 4$ \\
\hline & & & 191.12 & $9.18^{*} 10^{\wedge} 5$ \\
\hline & & \multirow{2}{*}{$>60$ years } & 145.95 & $6.11^{*} 10^{\wedge} 4$ \\
\hline & & & 176.18 & $2.25 * 10^{\wedge} 5$ \\
\hline & \multirow{4}{*}{ Male } & \multirow{2}{*}{$>30$ years } & 223.50 & $4.63 * 10^{\wedge} 6$ \\
\hline & & & 211.67 & $2.91 * 10^{\wedge} 6$ \\
\hline & & \multirow{2}{*}{$>60$ years } & 195.15 & $1.27^{*} 10^{\wedge} 6$ \\
\hline & & & 187.60 & $6.33^{*} 10^{\wedge} 6$ \\
\hline
\end{tabular}

Blood viral load: The results of RT-qPCR showed that the higher percentage of HCV infection was among patients of blood group B $(54.90 \%)$ and the lower percentage was among those of blood group O (9.90\%) with significant difference $(\mathrm{p}<0.05)$, (Fig. 9)

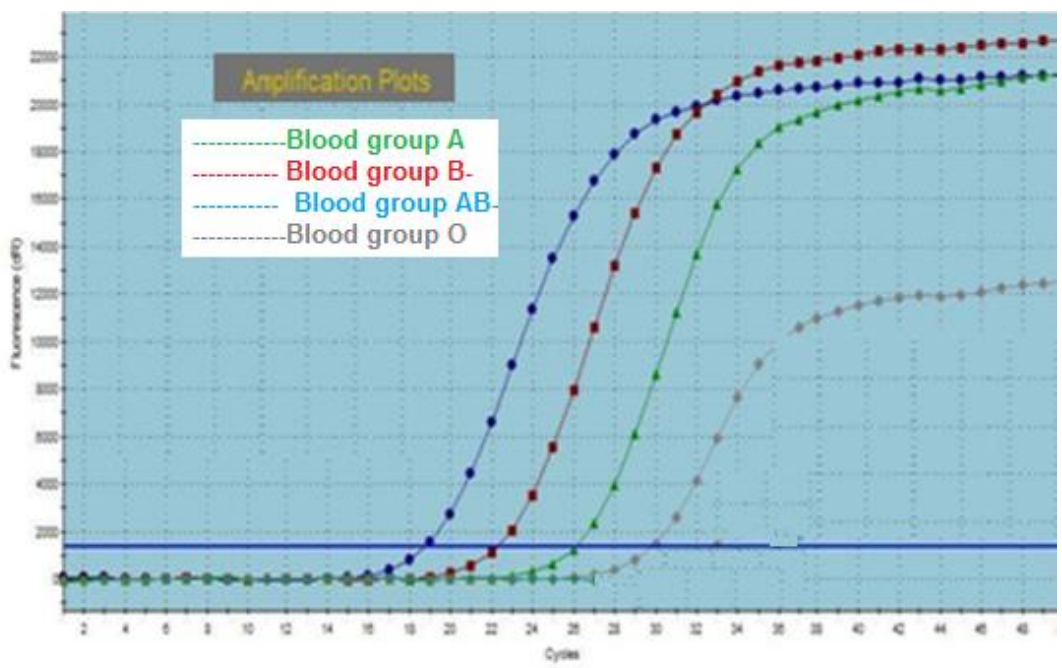

Fig. 9: The Graph of positive HCV obtained by RT-qPCR Thermocycler. 
The mean and median of viral load in IU/ml of blood in the study groups were : $\left(7 \times 10^{5}\right) ;\left(6.4 \times 10^{5}\right)$ $;\left(5.4 \times 10^{3}\right)$ and $\left(2.4 \times 10^{5}\right)$ in the groups of blood A,B,O and AB respectively. The highest mean was for blood donors while the lowest mean was for Polycythemic patients. The statistical analysis showed no significant differences ( $\mathrm{p}>0.05$ ) (Fig. 9).

\section{Discussion}

This is a study of possibility of investigation of a possible the association between $\mathrm{ABO}$ Blood/ Rhesus Grouping and HepatitisC virus Case in Egyptian patients. This association is corroborated by the dates back to a rather old study. For example, in a very recent study, Woo et al. (2013) showed that certain ABO blood groups may increase the risk of pancreatic cancer in patients with hepatitis $\mathrm{C}$

In the current study HCV disease was diagnosed in 90 patients , (54) males and (36)females with different age under studied distanced like symptoms of HCV disease collected from different hospitals belong to Alexandria, El Qalubyia and El Fayom. As well as 20 healthy cases under studied seropositivity belong to blood groups, A(23), B (26) , O (18) and AB (23 cases). The HCV disease was diagnosed based on Clinical Symptoms of hepatitis C, ELISA and rt-RT-PCR.

The highest percentage of HCV infection among blood group patients was blood group B followed by $\mathrm{A}, \mathrm{AB}$ and $\mathrm{O}$ for seroprevalence with significant differences. There was statistical no significant difference between patients and blood groups, $\mathrm{A}, \mathrm{B}$, and $\mathrm{AB}$ regarding $\mathrm{HCV}$ distribution in governorates whereas statistical significant decreased in Blood group $\mathrm{O}$ regarding medical history. On the other there was significant difference between female, male and age patients and blood groups, A, $\mathrm{B}, \mathrm{O}$ and $\mathrm{AB}$.It was found significant decrease in female than male cases. The age $>35$ was highly statistical significant increased compared with $>30 \mathrm{c},>40,>45$ and $>65$ age. On the other hand it was significant decreased blood groups $\mathrm{O}$ than blood groups, $\mathrm{A}, \mathrm{B}$ and $\mathrm{AB}$ regarding medical history. It was found that non-significant differences between $\mathrm{ABO}$ blood groups of HCV patient regarding CBC parameters, Biochemical Liver tests and Kidney function .This association is corroborated by the dates back to a rather old study. For example, in a study, Woo et al. (2013) showed that certain $\mathrm{ABO}$ blood groups may increase the risk of pancreatic cancer in patients with hepatitis $\mathrm{C}$ This is also in accordance with our finding. Although, exact underlying mechanism of association between $\mathrm{HC}$ infection and certain blood groups is not well-known, it can be hypothesized that there might be a shared receptor-binding affinity between the enveloped hepatitis $C$ virus and various cells in the body. Furthermore, it has been suggested that blood group antigens are receptors for several microorganisms (Kallenius et al., 1981). For example, in a study, Li et al. (2012) proposed that ABO blood group may contribute to increased risk of hepatocellular carcinoma in patients with HB infection. In another example, Wang et al. (2012) showed that there might be an association between A blood type and increased risk of pancreatic cancer in HB-positive case.

In Relationship between quantitative HCV RNA and HCV antibodies in HCV patients among blood groups regarding sex and age it was found that no related blood groups regarding sex and age, to HCV antibodies concentration and number of HCV RNA. On the other hand it was found that quantitative HCV RNA depended on concentration HCV antibodies in HCV patients . Percentages of RT-qPCR in Blood viral load of HCV positive infections according to blood groups . It was found higher percentage of $\mathrm{HCV}$ in blood group $\mathrm{B}$ and the lower in blood group $\mathrm{O}$ with significant difference. The low viral load in $\mathrm{IU} / \mathrm{ml}$ of blood in is the $\mathrm{O}$ group $\left(5.4 \times 10^{3}\right)$, medium load $\mathrm{AB}$ group $\left(2.4 \times 10^{5}\right)$ and high load $\mathrm{A}$ and $\mathrm{B}$ groups $\left(7 \times 10^{5}\right) ;\left(6.4 \times 10^{5}\right)$ respectively.

Surprisingly, unlike the results in the previous section, the findings revealed a significant association between certain blood groups with $\mathrm{HC}$ infections. These findings indicated that while $\mathrm{O}$ blood group was a factor of susceptibility toward HC infection, $\mathrm{AB}$ blood group was a protective factor. No significant role for Rh status was determined. In line with our findings, Behal et al. (2010) showed that there might be an association between ABO blood groups and $\mathrm{HC}$ infection in a study among a population of Indian blood donors. They reported that seroprevalence of HC virus was higher in $\mathrm{O}$ blood group individuals and lowest in $\mathrm{AB}$ blood group persons. There was not a significant association between $\mathrm{Rh}$ group and $\mathrm{HC}$ infection. 
Although, the mentioned study is not a well-designed case-control study, the results are completely in conformity with our findings. Caspari et al. (1997) also did not find a positive correlation between $\mathrm{Rh}$ groups and $\mathrm{HC}$ infection.

Despite these very important reports, hitherto there has not been any well-designed, case-control study for determining a definite association between $\mathrm{ABO}$ blood groups and $\mathrm{HC}$ infection; one of the main purposes of the current study. According to our findings, there was not a significant association between $\mathrm{ABO}$ blood groups, or Rh status, with chronic HB infection. In another similar report in Egypt, Alaoddolehei et al. (2007) and Eissa et al. (2007) confirmed that there was not a significant association between $\mathrm{ABO}$ blood groups and HB infection. This study was again a screening one on a group of blood groups and was not aimed to investigate a specific connection between blood groups and hepatitis B. This study also confirmed our findings in this regard.

Although, in studies have denied the first notion of Zuckerman and McDonald (1963), what is the main reason underlying this controversy? This might be justified by possible changes of HB virus in this long period of time, or defected accuracy of old equipments or methods in that era which possible might have led to wrong consequences which does not happen anymore by modern approaches at the current time.

\section{References}

Abo Elmagd, E.K., K.S. Abdel-Wahab, Z.E. Alrasheedy and A.S. Khalifa, 2011. An Egyptian study of mother to child transmission of hepatitis $C$ virus. Int. J. Virol., 7: 100-108.

Alaoddolehei, H., F. Sadighian and Z. Shahandeh, 2007. The study of ABO groups and Rh factor in active and non-active carriers of hepatitis B virus. Hepatitis Monthly, 72:43-44.

Barakat, A.F., A. Hegazy, R.E. Farag, A. Abdul Baky, L.F. Arafa and A. Farouk, 2012. Role of interferon-gamma and immune response biomarkers in predicting IFN-alpha responsiveness and treatment outcome in patients with hepatitis C virus. Int. J. Virol., 8: 288-298. Barth, H., T.J. Liang and T.F. Baumert, 2006. Hepatitis C virus entry: Molecular biology and clinical implications. Hepatology, 44: 527-535.

Behal, R., R. Jain, K.K. Behal and T.N. 2010. Variation in the host ABO blood group may be associated with susceptibility to hepatitis $C$ virus infection. Epidemiol. Infect., 138: 1096-1099.

Bidgoli, S.A., M.D. Zaverhei, M. Mohagheghi, B. Yazdanmehr, I. Jahanzad, N.E. Caspari, G., W.H. Gerlich, J. Beyer and H. Schmitt, 1997. Non-specific and specific anti-HCV results correlated to age, sex, transaminase, rhesus blood group and follow-up in blood donors. Arch. Virol., 142: 473-489.

Colucci, G., and R. Knobel, 2011. The COBAS ${ }^{\circledR}$ TaqMan ${ }^{\circledR}$ hepatitis C virus assays: automated systems for accurate and sensitive viral load quantification. Expert review of molecular diagnostics, 11(8), 793-798.

Daryani and F.A. Ardalan, 2007. Differential expression of uPA in chronic hepatitis B and C, liver cirrhosis and hepatocellular carcinoma: Comparison with normal liver tissues and liver metastatic tumors. Int. J. Cancer Res., 3: 25-32.

Eissa, S.A., L.M. Abdel Meguid, S.M. Ebeid, R.M. Abou Elfetouh and G.M., Abdel Moneim, 2007. National cancer institute experience in healthy Egyptian blood donors as regards blood group frequencies and seroprevalence of hepatitis B virus, hepatitis C Virus and HIV: 10 year evaluation. J. Egypt. Natl. Canc. Inst., 19: 71-76.

Hejazi, M.S., R. Ghotaslou, M.F. Hagh and Y.M. Sadigh, 2007. Genotyping of hepatitis C Virus in Northwest of Iran. Biotechnology, 6: 302-308.

Hemeida, A.A., M. Osman, M. El-Shahat, M.H. Hashem, A. Mahmoud and H. Dahi, 2011. Genetic variations in a conserved 5'-untranslated region of hepatitis C Virus isolated from Egypt. Int. J. Virol., 7: 91-99.

Kallenius, G., R. Mollby, S.B. Svenson, I. Helin, H. Hultberg, B. Cedergren and J. Winberg, 1981. Occurrence of P-fimbriated Escherichia coli in urinary tract infections. Lancet, 2: 13691372

Kilic, I.H., M.M. Koruk, M. Ozaslan, I.D. Karagoz and Y. Zer et al., 2012. Mutation analysis of protein kinase binding domain of HCV NS5A gene isolated from patients with chronic hepatitis C. Int. J. Pharmacol., 8: 519-526. 
Lavanchy, D., 2004. Hepatitis B virus epidemiology, disease burden, treatment and current and emerging prevention and control measures. J. Viral Hepat., 11: 97-107.

Li, Q., C.H. Yu, J.H. Yu, L. Liu and S.S. Xie et al., 2012. ABO blood group and the risk of hepatocellular carcinoma: A case-control study in patients with chronic hepatitis B. PLoS One, Vol. 7. 10.1371/journal.pone.0029928

Mandell, G.L., 2009. Principles and Practice of Infectious Disease. $7^{\text {th }}$ Edn., Churchill Livingstone, USA.

Quer, J., Gregori, J., Rodríguez-Frias, F., Buti, M., Madejon, A., Perez-del-Pulgar, S., \&Tabernero, D. (2015). High-resolution hepatitis C virus subtyping using NS5B deep sequencing and phylogeny, an alternative to current methods. Journal of clinical microbiology, 53(1), 219-226.

Rifat-uz-Zaman, 2006. Comparative immunogenicity of commercially available recombinant vaccines against hepatitis B in human urban population of Bahawalpur district, Pakistan. J. Boil. Sci., 6: 1053-1058.

Shepard, C.W., E.P. Simard, L. Finelli, A.E. Fiore and B.P. Bell, 2006. Hepatitis B virus infection: Epidemiology and vaccination. Epidemiol. Rev., 28: 112-125.

Sohail, M.N., F. Rasul, A. Karim, U. Kanwal and I.H. Attitalla, 2011. Plant as a source of natural antiviral agents. Asian J. Anim. Vet. Adv., 6: 1125-1152.

Wang, D.S., D.L. Chen, C. Ren, Z.Q. Wang and M.Z. Qiu et al., 2012. ABO blood group, hepatitis B viral infection and risk of pancreatic cancer. Int. J. Cancer., 131: 461-468. Woo, S.M., J. Joo, W.J. Lee, S.J. Park and S.S. Han et al., 2013. Risk of pancreatic cancer in relation to $\mathrm{ABO}$ blood group and hepatitis $\mathrm{C}$ virus infection in Korea: A case-control study. J. Korean. Med. Sci., 28: 247-251.

Zeisel, M.B., H. Barth, C. Schuster and T.F. Baumert, 2009. Hepatitis C virus entry: Molecular mechanisms and targets for antiviral therapy. Front. Biosci., 14: 3274-3285. Zuckerman, A.J. and J.C. McDonald, 1963. ABO blood groups and acute hepatitis. Br. Med. J., 2: $537-538$. 